\title{
Relationship between Budget Participation, Budget Procedural Fairness, Organisational Commitment and Managerial Performance
}

\author{
Killian Osikhena Ogiedu \\ Department Of Accounting \\ University Of Benin \\ Benin City \\ E-mail: koogiedu@ yahoo.com \\ Phone: 08033600045 \\ \& \\ James Odia (PhD) \\ Department Of Accounting \\ University Of Benin \\ Benin City \\ E-mail: odiajames@yahoo.com \\ Phone: 08056580011
}

\begin{abstract}
This study examines the role of budgetary participation, procedural fairness and organizational commitment on managerial performance. It presents the results from a sample of supervisors in Nigerian manufacturing industries using the questionnaire method and the ordinary least squares analysis as the analytical tool. The results show that there is a three way interaction between budget participation, budget procedural fairness and organizational commitment that influence managerial performance. The study recommends, that in order to increase managerial performance, managers should be allowed full participation in budget preparation and that the budget procedures should be fair.
\end{abstract}

\section{Introduction}

In the present day competitive operating environment, there is increasing need for corporations to increase managerial performance. One of the ways which has been suggested in the literature is managerial participation in budgeting. Budget participation implies that top managers and their subordinates jointly contribute in the determination process for resources use and generation in their own activities and operations. In other words, budget participation has an influence on managerial performance. A budget is not only a financial plan that sets forth cost and revenue goals for responsibility centres within a business firm, but also communication, performance evaluation, and motivation (Kenis, 1979). Organization theorists have asserted that there it a positive relationship between employee performance and participation in budgeting or goal setting (Kenis, 1992).

There has been considerable literature on the motivational and cognitive mechanisms by which participation may be related to employee performance (Lock et al, 1986; Murray, 1990). Some researchers have found that there is a positive relationship between participation and motivation (Merchant, 1981) while others did not (Brownell and Mcinnes, 1986). This led to the suggestion 
by Brownell and Mcinness (1986), that future researches should examine how participation influences performance without the mediatory effect of motivation. Other accounting researchers examined how cognitive factors explain the effect of participation influence performance. Brownell (1988) finds that budgetary participation provided information that reduced role ambiguity which contributed to improved performance. Also Mia (1989), found the relationship between participation and performance to be moderated by job difficulty. Many other researches have been conducted on the relationship between budget participation and performance and the explanatory variables. However these researches have not developed comprehensive models that adequately explain the intervening factors between budgetary participation and performance.

This study therefore examines (against the background of prior studies) the role of budgetary participation, procedural fairness and organizational commitment on managerial performance. The remaining part of the study is divided into five (5) sections. The first examines the existing literature and develops the hypotheses. The next section is on the research methodology including measurement of variables and the research model. The third section summarises the findings of the study while fourth section is on results and discussions. The last section deals with the conclusion and recommendations.

\section{Literature Review and Hypothesis Development}

The relationship between budget participation and performance has a long history in the managerial accounting literature (Leach-Lopez et al, 2007). In fact budget participation has been one of the most researched topics in management accounting for over 40 years (Shields and Shields, 1998; Eker, 2008). Some of these studies have examined the effect of participative budgeting on managerial performance through various view points such as expectancy theory (Brownell and Mclinnes, 1986), cognitive dissonance theory(Tiller, 1983); person environment- fit theory(Shields, Deng and Kato, 2000); organizational justice theory(Libby,1999, 2000) and role theory(Chenhall \& Brownell, 1986). These studies only provided piecemeal evidence to these relationships. For example (Kennis, 1979) argued that budget participation is positively and significantly associated with performanace while Milani (1975) finds a weak positive relationship between participation and performance. On the other hand, Bryan and Locke (1967) find a negative relationship between participation and performance. The inconsistency in the results led to the examination of various mediating variable between budget participation and managerial performance: role ambiguity (Becker and Gren, 1962); national culture (Lau and Buckland, 200; Tsui, 2001), organizational culture (Goddard, 1997; O’Connor, 1995; Subramaniam \& Ashkanasy, 2001); environmental uncertainty (Govindarajan, 1986; Gul, 1991; Dunk \& Lysons, 1997); market

competition (Chong et al, 2005); information asymmetry (Dunk, 1993; Chow et al, 1988); task characteristics (uncertainty/difficulty)(Brownell \& Hirst, 1986; Brownell \& Dunk, 1991); Lau \& Tan, 1986: Orpen, 1991); Locus of control (Brownell, 1981, Brownell, 1982); supervisory evaluative style (Brownell, 1981; Brownell \& Hirst, 1986, Brownelll \& Dunk, 1991); job related information (Kren, 1992; Chong \& Chong, 2002; Chong \& Johnson, 2007; Magner, Welker \& Compbell, 1996; Shields \& Shields, 1998); management Accounting systems (Choe, 1998; Tsui, 2001) and organizational commitment (Noun \& Parker, 1998); job relevant information (Eker,2008) among other variables. 
We contribute to this literature by examining the relationship between budget participation and managerial performance with mediating variables as budget procedural fairness and organizational commitment among Nigerian managers working in Nigerian registered companies. The dependent variable was managerial performance while the independent variable budget participation, budget procedural fairness and organizational commitment. Their interactions were investigated for their impact managerial performance. In the following subsections, we examine the dependent variable and the independent variables.

\section{Budget participation and managerial performance.}

The relationships between budget participation and managerial performance can be viewed from two perspectives viz psychological and cognitive perspectives. First, because of identification and involvement with budget goals, participation is related to performance and consequently leads to enhanced motivation and commitment to performance and consequently leads to enhanced motivation and commitment to the budget (Murray, 1990; Chow et al 1988; Lau \& Buckland, 2001). Secondly as a result of improving flow of information between superiors and subordinates, budget participation leads to higher quality decisions. Viewed from these perspectives, participation leads to higher motivation, higher commitment, higher quality decision and higher performance.

Previous empirical studies indicate that the relationship between budgetary participation and performance is inconsistent. The results of some the studies indicate a positive relationship (Merchant, 1981; Brownell, 1982) while some indicate positive insignificant relationship (Milani, 1975; Brownell \& Hirst, 1986; Dunk, 1989). Some other studies indicate negative relationship (Stedry, 1960; Cherrington \& Cherrington, 1973). Prior studies indicate that participation in budgetary setting benefits managers in many ways, such as showing job-related information (Parker \& Kyj, 2006 ), decreasing information asymmetry (Kien, 1992), diminishing managers role ambiguity (Chenhall \& Brownell, 1988) and reducing job related tension (Kennis, 1995; Shields, et al, 2000). However as stated earlier, these studies provides inconsistent results for budgetary participation's effect on performance. Thus we propose that:

H1: There is a positive relationship between budget participation and managerial performance.

\section{Budgetary procedural fairness and managerial performance}

Procedural and interactional fairness in organizational decision making, have been examined in a number of contexts including budgeting and related settings such as pay allocation and performance appraisal (Broker \& Wiesenfeld, 1996; Colquith et al, 2001 and Greenberg, 1990). Procedural fairness theory is concerned with the impact of the fairness of decision making procedures on the attitudes and behaviour of the people involved in and affected by those decisions (Lind \& Tyler, 1998; Levanthel, 1980).

Procedural fairness recognizes the positive benefits of allowing employees to participate in decision-making(Lind \& Tyler, 1988; Maiga \& Jacobs, 2007). Empirical studies have found, that a decision maker's behaviour was significantly related to perceptions of procedural 
fairness(Shapiro \& Breth, 1993). Studies have found that even if outcomes are not favourable to an individual, they are less likely to be dissatisfied with these unfavourable outcomes, if they believe that procedures used to derive them are fair (Lind \& Tyler, 1988; Folger \& Bies, 1989).

There is scant literature on the simple and direct relationship between budgetary procedural fairness and managerial performance. However, from the above there is a link between procedural fairness and employee satisfaction and hence employee performance. This invariably means that there is a positive relationship between procedural fairness and managerial performance. We thus hypothesis that:

H2: There is a positive relationship between budgetary procedural fairness and managerial performance.

\section{Organizational commitment and managerial performance}

According to Laka-Mathebula (2004), organizational researchers agree that a consensus has not yet been reached over the definition of organizational commitment (Mowday, 1998; Suleiman \& Isle, 2000a; 2000b; Tangaro, 2001). The way organizational commitment is defined depends on the approach to commitment that one is adhering to (Scholl, 1981). In this direction, organizational commitment is defined either as an employee's attitudes or as a force that binds an employee to an organization.

Participation in decision making enhances effective organizational commitment (Nodes and Steers, 1981; Mayer \& Schoorman, 1998). Earlier studies have suggested that manager's participation will enhance their organsational commitment (Magner et al, 1995; Nouri \& Parker, 1998; Parker \& Kyj, 2006). Employee's organizational commitment and job satisfaction are positively correlated (Vanderberg \& Lanke, 1992; Liou, 1995). Previous studies indicate that affective organizational commitment benefit employee's performance (Allen \& Meyer,1996; Randall, 1990; Riketa, 2002). When managers have committed to an organization, they will accept organizational goals and involve more effort to attain the goals and improve their performance. This leads us to the third hypothesis:

H3: There is a positive relationship between organizational commitment and managerial performance.

\section{Variable interactions}

There have been various studies on the interactions between various variables to determined their joint affects on managerial performance. We examine below, the various interactions among the variables.

\section{Budget participation, procedural fairness and managerial performance}

According to Sholihin et al (2007), the term 'procedural fairness' was first used by Thibaut et al (1974) and Thibaut and Walker (1975) to refer to the social psychological consequences of procedural variation with particular emphasis on fairness judgments (Lind \& Tyler, 988). Libby (1999) examines the relationships between the use of fair budgeting process and subordinates' 
performance and found that the combination of participation and procedural fairness leads to improved performance. Wentzel (2002) finds that budgetary participation has no significant direct effect on either managerial performance or budgetary performance. Rather, the effect was indirect through a high perception of fairness that was translated into higher commitment to the budget goals. We thus hypothesis that:

H4: There is a positive interaction between budget participation and procedural fairness that influences managerial performance.

\section{Budget participation, organization commitment, and managerial performance}

Nouri and Parker (1998) find from their study that budget participation affect job performance by means of organizational commitment as an intervening variable. Many studies on organizational commitment assert that democratic and participatory processes in general, are quite significant for the development of this sense. The basic idea of participative decision making (including participative budgeting) is that employees should adopt decisions made by participative method and try to apply the decision to being successful. In this way, participation serves to integrate employees in the organization and commit them to organizational decisions (Lincoln \& Kalleberg, 1985). Thus as participation of personnel to decision making is improving, the feeling of organizational commitment also increase. This creates an effect to increase their performance. Participatory budget as one of the participation channels has an important role to play in bringing about these positive effects. Budget participation is a variable, which has the strongest effect an all the motivation variables. (Milani, 1975; Frucot \& Shearon, 1991). This leads us to the next hypothesis:

H5: There is a positive interaction between budget participation and organizational commitment that influence managerial performance.

\section{Budget participation procedural fairness, organizational commitment and managerial performance}

There are no studies on the combined intervening effects of procedural fairness and organizational commitment on the relationship between budget participation and managerial performance. However, this effects can be inferred from previous other studies that pertain to the respective variables. Lau and Lim (2002 a, 2002b) use a survey method to investigate the effects of procedural justice in performance evaluation. Both studies find that procedural fairness is associated with managerial performance. Lau and Lim (2000a) find that the effect of procedural fairness on managerial performance is indirect via budget performance. Mayner et al (1995) asserts that budget participation affect subordinates' trust in supervisors which could lead to trust in the organization and consequently greater organization commitment. The greater organizational commitment will in turn lead to higher managerial performance. In other words, where managers participate in the budgeting process and there is procedural fairness, such managers will have a sense of organization commitment which in turn will lead to higher performance on their part. This leads us to the principal hypothesis:

H6: There is a three way interaction between budget participation, budget procedural fairness and organizational commitment that influences managerial performance. 


\section{Research Method Sample and data collection}

This study employs a cross sectional questionnaire survey to collect empirical data from a sample of 200 subordinate managers who were randomly selected from manufacturing companies quoted in the Nigerian stock exchange. A questionnaire with a covering letter was physically administered to the subordinate managers who play a role in the budgeting process and also have accounting responsibility for the budget results. Approximately $40 \%$ or 50 of the respondents returned the questionnaire. 45 or $56.3 \%$ of the returned questionnaire were found usable. Thus the final response rate was $22.5 \%$. The following criteria were used for declining a questionnaire usable. (i) The particular respondent had a budget responsibility in the unit; (ii) The unit was an investment center, and (iii) The respondent has held the position for at least two years

\section{Measurement of variables}

The variables used to test the hypothesis are budget participation, budget procedural fairness, organizational commitment and managerial performance. (see appendix for an extract of he questionnaire).

Milani's six item measures, used previously in studies of their type was used to asses the subordinate managerial degree of participation in the budget process. The Milani's response scale is a seven point Likert type scale. However, in this study, scale has been reduced to a five point Linkert type scale to align the measures with others in the research instrument as well as simplify if for the research environment.

Procedural fairness was assessed using an eight item Linkert scale type questionnaire. Six of the items were adapted from Magner and Johnsons (1995)'s scale, which pertain to five of Leventhal's (1980) six rules for determining the fairness of allocation procedure. The two remaining questions were developed to address Levenhal (1980)'s representative role and the informational fact of procedural fairness (Greenberg, 19930). Maiga and Jacobs (2007) used the eight point Linkert scale described above. Just like the scale for budget participation, the scale was reduced from seven point to a five point Linkert scale.

Organizational commitment was measured using a nine item scale developed by Mowday et al and used by Nouw and Parker (1998). The scale is a five point Linkert type scale. Managerial performance was measured by the Linkert type scale developed by Mahoney et al (1965).

\section{Research Model}


The principal framework for the study of the relationship among the variable is established here. The mathematical model presented below was used to test the hypothesis using the Ordinary Least Square Regression Method.

$Y=b_{0}+b_{1} X_{1}+b_{2}+X_{2}+b_{3}+X_{3}+b_{4} X_{1} X_{2}+b_{5} X_{1} X_{3+}+b_{6} X X_{3}+b_{7} X_{1} X_{2} X_{3+e}$

Where

$\mathrm{Y} \quad=$ Managerial performance

$\mathrm{B} \quad=$ Constant

$\mathrm{X}_{1} \quad=$ Budget Participation (BP)

$\mathrm{X}_{2} \quad=$ Budget Procedural Fairness $(\mathrm{BPF})$

$\mathrm{X}_{3} \quad=$ Organizational Commitment (OC)

$\mathrm{X}_{1} \mathrm{X}_{2}=$ two way interaction between budget participation and procedural fairness (BP)(BPF)

$\mathrm{X} 1 \mathrm{X} 3$ =two way interaction between budget participation and organizational Commitment $(\mathrm{BP})(\mathrm{OC})$

$\mathrm{X}_{2} \mathrm{X}_{3}=$ two way interactive between procedural fairness and organizational commitment $(\mathrm{PF})(\mathrm{OC})$

$\mathrm{X}_{1} \mathrm{X}_{2} \mathrm{X}_{3}=$ three way interaction between procedural fairness and organizational commitment $(\mathrm{BP} / \mathrm{BPF} / \mathrm{OC})$

$\mathrm{E} \quad=\quad$ error term

\section{Results}

The study consists of two main divisions namely, the interaction model (principal model) that investigates the interaction of the variables that determine managerial performance and the unit models that examine the effects of the individual variables and lower levels of interactions of these variables on managerial performance. We shall first examine the principal three factors model involving the highest level of interactions among the variables.

The model consists of four factors (budget participation, budget procedural fairness, organizational commitment and managerial performance). The measures of fit are assessed using structural equation modeling. There is no consensus on a single set of measure of fit (Murayana, 1998). The standard practice is to report several measures (Maiga \& Jacobs, 2007). In this study, we utilize the R bar squared, the Durbin Watsin Statistic and the F-statistic to assess the fitness of the regression models. The regression uses an alpha significance level of 5\%. This is consistent with conventional guidelines on accounting research (Kerlinger, 1986). The result of the repression of the three - way interaction model is shown in table 1 below.

\section{Table 1 Ordinary Least Squares Estimation For Three Factor Model}

Dependent variable is $\mathrm{Y}=$ Managerial Performance 45 observations used for estimation from 1 to 45

$\begin{array}{lllll}\text { Regressor } & \text { Coefficient } & \text { Standard Error } & \text { T-Ratio } & \text { [Prob] } \\ \text { A } & -2.4645 & 1.7993 & -1.3697 & {[.179]} \\ \text { BP } & -1.1734 & 0.7852 & -1.4942 & {[.144]} \\ \text { BPF } & 4.9853 & 2.1041 & 2.3693 & {[.023]} \\ \text { OC } & 5.6987 & 2.0243 & 2.8152 & {[.008]}\end{array}$




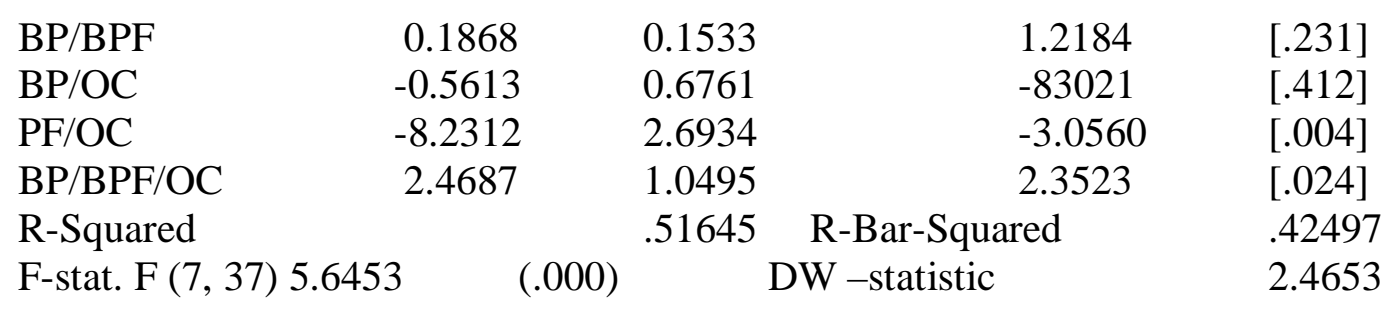

It was hypothesized that the three independent variables would interact to affect managerial performance. Thus, it was expected that the coefficient of the three-way interaction term, b7 would be statistically significant (Dunk, 1993). The results in table 1 above, indicate that b7 is significant at $\mathrm{p}=0.024$. The $\mathrm{R}$ squared is 0.51645 while the $\mathrm{R}$ bar squared is 0.42497 . $\mathrm{R}$ bar squared is considered a better measure of goodness of fit because it takes into account the loss of degree of freedom associated with adding extra variables (Brooks, 2002). The R bar squared of 0.424977 means that the proposed model explains $42.497 \%$ of the variations in the independent variable, namely managerial performance. This percentage is acceptable because the model did not contain all the variables known to affect managerial performance.

The Durbin Watson statistic for the regression is 2.4653. The Durbin Watson statistic tests the null hypothesis that the residuals from an ordinary least square regression are not auto correlated against the alternative that the residuals are auto-correlated (see Durbin and Watson, 1951). It is a test for first order correlations. The Durbin Watson statistic ranges in value from 0 to 4 . A value of 2 indicates non-correlation in the residuals while a value of 0 indicates perfect negative autocorrelation (Brooke, 2002). The model value of 2.4653 is close to 2, indicating that there is no auto correlation.

The last statistic used to assess the fitness of the model is the $\mathrm{F}$-statistic which measure the overall fit of the model (Brooks, 2002). The $\mathrm{R}$-statistic is used by comparing the model value of $\mathrm{F}(7,37)=5.6453$ is greater than the critical value of 2.306 . This means that there was an overall goodness of fit.

No attempt was made to interpret the results of significance tests for the main effects (direct effects of the independent variables) and the two way interactions terms since the variables are not measured on ratio scales (Southwood, 1978; Dunk, 1993). Southwood (1978) demonstrated that the coefficient of main effects and lower-order interaction terms together with their statistics are arbitrary if ratio scales are not employed. Thus the main effects and lower level interactions are tested using univariate regression analysis.

The first hypothesis in the series says that there is a positive relationship between budget participation and management performance. The ordinary least squares estimation results are shown in table 2 below.

\section{Table 2 Ordinary Least Squares Estimation For Budget Participation}

$\begin{array}{lllll}\text { Regressor } & \text { Coefficient } & \text { Standard Error } & \text { T-Ratio } & \text { [Prob.] } \\ \text { A } & 0.71850 & 0.075725 & 9.4884 & {[.000]} \\ \text { BP } & 0.21310 & 0.088261 & 2.4144 & {[.020]}\end{array}$




$\begin{array}{llll}\text { R-Squared } & .11938 & \text { R-Bar-Squared } & .09890 \\ \text { F-stat. F }(1,43) & 5.8293(.020) \mathrm{DW}- & \text { statistic } & 2.2670\end{array}$

The Univariate model between budget participation and managerial performance is significant at $\mathrm{P}=0.02$. The $\mathrm{R}$ squared is 0.11938 while the $\mathrm{R}$ bar squared is 0.098902 . This means that budget participation explains only $9.89 \%$ of the variations in managerial performance. This is understandable as budget participation is only one of the many factors that affects managerial performance. The Durbin Watson Statistics is 2.2670 which is close to 2. This means that there is no autocorrelation in the residuals. The model value of $F(1,43)=5.8293$ is greater than the table value of 4.053. This means that there is an overall goodness of fit in the relationship between budget participation and managerial performance. Thus the hypothesis is accepted.

The second hypothesis says that there is a positive relationship between budgeting procedural fairness and managerial performance. The ordinary least squares estimation results are shown in table 3 below.

\section{Table 3 Ordinary Least Squares Estimation For Budget Fairness}

Dependent variable is $y=$ managerial performance

45 observations used for estimation from 1 to 45

\begin{tabular}{lllrl} 
Regressor & Coefficient & Standard Error & T-Ratio & [Prob.] \\
A & .60170 & .12885 & 4.6696 & {$[.000]$} \\
BPF & .35032 & .15099 & 2.3202 & {$[.025]$} \\
R-Squared & .11126 & \multicolumn{2}{c}{ R-Bar-Squared } & .09059 \\
F-stat. F $(1,43)$ & $5.3833[.025]$ & \multicolumn{2}{c}{ DW-statistic } & 2.2161
\end{tabular}

From the table $\mathrm{R}$ squared is 0.11126 while the $\mathrm{R}$ bar squared is 0.090596 . The $\mathrm{R}$ bar squared of 0.090596 means that budgeting procedural fairness explain $9.0596 \%$ of the variations in managerial performance. The Durbin Watson Statistics of 2.2161 is close to 2 indicating that there is no auto-correlation in the residuals. The calculated value of $\mathrm{F}(1,43)=5.383$ is greater than the critical value of 4.053 which means that there is an overall goodness of fit. Above all, the regression coefficient is significant at $\mathrm{P}=0.025$ which is within the significance level of $\mathrm{P}=$ 0.05 . Thus the hypothesis is accepted.

The next hypothesis says that there is a positive relationship between organizational commitment and managerial performance. The ordinary least squares estimation result is shown in table 4 below.

Table 4 Ordinary Least Squares Estimation for Organizational commitment. Dependent variable is $\mathrm{y}=$ managerial performance 45 observations used for estimation from 1 to 45

$\begin{array}{llllr}\text { Regressor } & \text { Coefficient } & \text { Standard Error } & \text { T-Ratio } & \text { [Prob] } \\ \text { A } & .54843 & .14986 & 3.6595 & {[.001]} \\ \text { OC } & .41804 & .17793 & 2.3495 & {[.023]} \\ \text { R-Squared } & .11377 & \text { R-Bar-Squared } & & .0931 \\ \text { F-stat. F }(1,43) & 5.5203[.023] & \text { DW -statistic } & & 2.3216\end{array}$


From the table, $\mathrm{R}$ squared is 0.11377 while $\mathrm{R}$ bar squared is 0.093163 . This means that organizational commitment explains $9.32 \%$ of the variations in managerial performance. The Durbin Watson Statistics is 2.3216 which is close to 2. This means that there is no autocorrelation in the residuals. The calculated value of $\mathrm{F}(1,43)=5.5203$ is greater than the critical value of 4.053. This means that there is an overall goodness of fit. Also the regression coefficient is significant at $\mathrm{P}=0.023$ which is within the thresh old value of $\mathrm{P}=0.05$. Using the above statistics, the hypothesis is accepted.

The next hypothesis says that there is a positive interaction between budget participation and procedural fairness that influences managerial performance. The ordinary least squares estimation for this interaction is shown in table 5 below.

\section{Table 5 Ordinary Least Squares Estimation for Budget Participation and Budget Procedural Fairness}

Dependent variable is $\mathrm{y}=$ managerial performance

45 observations used for estimation from 1 to 45

$\begin{array}{lllrl}\text { Regressor } & \text { Coefficient } & \text { Standard Error } & \text { T-Ratio } & \text { [Prob] } \\ \text { A } & .71730 & .052874 & 13.5663 & {[.000]} \\ \text { BP/BPF } & .25806 & .073618 & 3.5053 & {[.001]} \\ \text { R-Squared } & .22225 & \text { R-Bar-Squared } & .20416 \\ \text { F-stat. F }(1,43) & 12.2874[.001] & \text { DW -statistic } & 2.1220\end{array}$

From the table, $\mathrm{R}$ squared is 0.22225 while $\mathrm{R}$ bar squared is 0.20416 . This means that the interactions between budget participation and budget procedural fairness explain $22.225 \%$ of the variations in managerial performance. The regression coefficient is significant at $\mathrm{P}=0.001$. The Durbin Watson Statistic is 2.1220 which is close to 2 and therefore acceptable. The table value of $\mathrm{F}(1,43)=12.2874$ is greater than the critical value of 4.053. This means that there is an overall goodness of fit. Thus the hypothesis is accepted.

The next hypothesis says that there is a positive interaction between budget participation and organization al commitment that affects managerial performance. The regression results are shown in table 6 below.

Table 6 Ordinary Least Squares Estimation for Budget Participation and Organizational Commitment

Dependent variable is $\mathrm{y}=$ managerial performance

45 observations used for estimation from 1 to 45

\begin{tabular}{lllll} 
Regressor & Coefficient & Standard Error & T-Ratio & [Prob.] \\
A & .64590 & .068804 & 9.3875 & {$[.000]$} \\
BP/OC & .35613 & .095660 & 3.7229 & {$[.001]$} \\
R-Squared & \multicolumn{2}{c}{.24375} & R-Bar-Squared & .22617 \\
F-stat. F $(1,43)$ & \multicolumn{2}{c}{$13.8598[.001]$} & DW -statistic & 2.3165
\end{tabular}

From the table, $\mathrm{R}$ squared is 0.24375 while $\mathrm{R}$ bar squared is 0.22617 meaning that the interactions between budget participation and organizational commitment explains $22.617 \%$ of 
the variations in managerial performance. The Durbin Watson Statistic of 2.3165 from the regression results is close to 2 , which means there is no autocorrelation. The calculated value of $\mathrm{F}(1,43)=13.8598$ is greater than the critical value of 4.052 indicating that there is an overall goodness of fit. The regression coefficient is significant at $\mathrm{P}=0.001$ which is less than the threshold value of $P=0.05$. Thus the hypothesis is accepted.

\section{Discussion of Results}

The study proposes two brood classes of hypothesis - the principal hypothesis and other subsidiary hypotheses. The principal hypothesis is based on the principal model which establishes the effect of the three-way interactions of budget participation, budget procedural fairness and organizational commitment on managerial performance. The other group of hypotheses examines the effect of the individual variables and their lower level interactions on managerial performance. The results show that there is a positive interaction between budget participation, budgeting procedural fairness and organizational commitment that affects managerial performance. However, the results show that the theoretical structural principal model provides only a limited explanation for the variations in managerial performance. This is understandable as there are other variable other than three in the model that affects managerial performance. Though there have been many studies in the relationship between budget participation and managerial performance, no study has examined the combined moderating effects of budget procedural fairness and organizational commitment.

The first hypothesis says that there is a positive relationship between budget participation and managerial performance. This proposition was accepted by the study. This is in line with the position of merchant, 1981, Brownell, 1982 among others. It however, contrasts with the position of Stedy, 1960 and Cherrington and Cherrington, 1973) subsidiary who finds that there is a negative relationship between budget participation and managerial performance.

The next hypothesis says that there is a positive relationship between budgetary procedural fairness and managerial performance. This position was also supported by the study. There is scanty literature on the direct relationship between budget procedural fairness and managerial fairness.

The study also supported the hypothesis that there is a positive relationship between organizational commitment and managerial performance. This is in line with the findings of Allen and Meyer, 1996; Randall, 1990; and Riketa, 2002. The next hypothesis is on the effect of the interaction between budget participation and budgetary procedural fairness on managerial performance. This position was supported by the study just as the effects of the interaction between budget participation and organizational commitment. There is however, scantly literature on these interactions. 
The effects of the variables are observed from the study of the principal model and the subsidiary models. From the results, the variables explain very little variations in managerial performance. However, when these variables interact, they progressively explain higher proportions of the variations of in the defendant variable. The three ways interaction model gave the highest explanations of the variations in managerial performance.

\section{Summary of Findings}

This study was carried to examine the role of budgetary participation, procedural fairness and organizational commitment on managerial performance. From the study, the following major findings were made: (i) There is a positive relationship between budget participation and managerial performance.(ii) There is a positive relationship between budgetary procedural fairness and managerial performance.(iii) There is a positive relationship between organizational commitment and managerial performance(iv) There is a positive interaction between budget participation and procedural fairness that influences managerial performance (v) There is a positive interaction between budget participation and organizational commitment that influence managerial performance (vi) There is a three way interaction between budget participation, budget procedural fairness and organizational commitment that influences managerial performance.

\section{Conclusion and Recommendations}

Overall, the results show that there is a positive three way interactions between budgetary participation, budgetary procedural fairness and organizational commitment that affects managerial performance. The study also finds that there is a positive relationship between budget participation, budget procedural fairness and organizational commitment respectively on managerial performance. The results have both theoretical and practical implications. The study, from a theoretical perspective, extends our understanding of some of the factors that affect managerial performance in a budgeting setting. The study also critically illuminated the interactions among these variables.

From a practical viewpoint, the results of the study have implication for managerial motivation and performance in a budgetary setting. It explains how budget participation and budgetary procedural fairness can lead to organizational commitment and eventually to managerial performance. Thus to increase managerial performance it is recommended that managers should be involved in the budgetary process. Also the budgetary procedures should be fair to ensure organizational commitment that would translate into higher managerial performance.

\section{References}

Allen, N.J \& Meyer, J.P (1984). The measurement and variables association with affective, continuance and normative commitment to the organization, Journal of Occupational Psychology, 63:1-18

Banker, S.W \& Gren, D. (1962) Budgeting and employee behavior, Journal Of Business" $35: 352-402$ 
Becker T.E, Randall, D.M. \& Reigel, C.D. (1995). The multidimensional view of commitment and the theory of reasoned action: A comparative evaluation, Journal of Management,

$21 \quad(4): \quad 616-639$

Becker, H.S (1960) Notes on the concept of commitment, American Journal of Sociology, $632-40$

Benko, H.B (1997) Disengaging organizational commitment, Personal Review, 26:144 - 131

Broker, J. and Signed,P.A. (1996). Understanding the interaction between procedure justice and distribution justice: The role of trust in organization, in trusts in organizations, Eds, R,M Kramer \& T.R.Tyler: 390 - 413 Thousand Oaks, Ca: Sage

Brooks, C. (2002) Introductory Econometrics for Finance, Cambridge: Cambridge University press.

Brownell, P \& Mclnnes, M. (1986) Budgetary participation, motivation and managerial performance, The Accounting Review 61 (October): 587 - 600

Brownell, P. (1982) A field study examination of budgetary participation and locus of control, The Accounting Review, 57:766 - 777.

Brownell, P.(1981) Participating in budgeting, locus of control and organization effectiveness The Accounting Review, 56: $844-860$

Brownell, P \& Dunk, A.S. (1991) Task uncertainly and its emphasis: some methodological issues and empirical investigation, Accounting, Organization

and Society, 16:693 - 703

Brownell, P. \& Hirst, M. (1986) Reliance on accounting information, budgetary participation and task uncertainly: test of a three - way interaction, Journal of Amounting Research, 24:241 - 249

Brownell, P. \& Mclnnes, M.(19986) Budgetary participation, motivation and managerial performance, The Accounting Review, 61(4) 587 - 600

Bryan, J \& Locks, E.A. (1967). Goal setting as a means of increasing motivation, Journal of Applied Psychology, June

Chenhall, R.H \& Brownell, P. (1988) The Effect of participative Budgeting on Job Satisfaction and Performance: Role ambiguity as an intervening variable, Accounting, Organization and society 13(3): 225 - 233

Chenhall, R.H \& Brownell, P (1988) The Effects of Participative Budgeting On Job Satisfaction and Performance: Role Ambiguity as an Intervening Variable Accounting, Organisation And Society 13(3): 225 - 233.

Cherrington, D.J. \& Cherrington, J.O. (1973) Appropriate reinforcement contingencies in the budgeting process, Journal Of Accounting Research Supplement 11:225-253

Choe, J.M (1998) The effects of user participation on the design of accounting information system, Information and Management, 34:185 - 198

Chong, V.K \& Chong, K.M. (2002) Budget goal commitment and information effects of budget participation on performance: A structural equation modeling approach Behavioural Research In Accounting 14:65 - 86 
Chong, V.K, Eggleton , L.R.C. \& Leong, M.K.C. (2005) The Impact Of Market Competition And Budgetary Participation On Performance And Job Satisfaction: A Research Note, The British Accounting Review, 37:115-133

Chong, V.K \& Johnson, D.M. (2007) Testing a model of the antecedents and consequences of budgetary participation on job performance, Accounting And Business Research, 37(1): $3-19$

Chow, C, Cosperand, J.C.,\& Waller, W.S.(1988) participative budget effects of a truth including pay scheme and information asymmetry in slack and performance, The Accounting Review Lx111-122

Colquitt, J.M, Wesson, C.O. , Porter, L.H., \& Colon, D.E. (2001) Justice at the millennium: A meta - analytic review of 25 years of organizational justice research, Journal $O f$ Applied Psychology, 86: 425 - 445

Dunk, A.S \& Lysons, A.F. (1997) An analysis of department effectiveness, participative budgetary control process and environmental dimensionality within the competing value: a public $\quad$ sector study, Financial Accountability and Management, 13(1): 1 -

15

Durbin, J. \& Watson, G.S (1951) Testing for serial Correlation in list squares, Bionetrika, 38: 159-190.

Eker, M (2008) The effect of the relationship between budget participation and job relevant information on managerial performance, Ege Academic review, 8(1): 183 - 198

Fangaro, G.A.(2001) Organization commitment: a concept analysis, Nursing $\quad$ Forum,36, (2): $14-23$

Folger R \& Bies, R.J. (1989) Managerial responsibilities and procedural justice, Employee Responsibilities and Light Journal, 2: 79 -90

Goddard, A (1997) Organization culture and budgetary control in a uk local government organization, Accounting and Business Research, 27(2): 111- 123

Govindarajan, V. (1997) Impact of participation in the budgetary process on management attitudes and performance: universalistic and contingency perspective, Decision Sciences, February: 496 - 516

Greenberg, J (1990) Organisational justice: yesterday, tomorrow, Journal Of Management $16: 399-432$.

Greenberg, J. (1993) The social side of fairness: interpersonal and information classes of the organization justice In Justice In The Workplace: Approaching Fairness In Human Resources Management, $R$. Cropanzano (Ed), 79 -103, hilldale , NJ: Lawrence Eribaum.

Gul, F.A (1991) The effect of management accounting system and environmental uncertainly on small business managers' performance, Accounting and Business Research Winter:57 61

Kenis, L. (1979): Effects of budgetary goal characteristics on managerial attitudes and performance, The Accounting Review, October: 707 - 721

kerlinger, F.N. (1986) Foundation of behavioral research, New York, Nigh; Prentice Hall

Kren, L (1993) Budgetary participation and managerial performance: the impact of information and environmental volatility, The Accounting Review, 67 (3):511 - 526 
Laka - Mathebula, M.R. (2004) Modeling The relationship Between organization commitment, leadership style, human resources management practice and organization trust, PHD, thesis, faculty of economics and management sciences, universities of Pretoria, south Africa

Lau, C.M \& J.J Tan (1998) The impact of budget emphasis, participation and task difficulty and performances: the financial services sector, Management Accounting Research 9:163183

Lau, C.M. \& Buckland, J. (2000) Budget emphasis, task difficulty and performance: The effect of diversity within culture, Accounting and Business Research Winter,: 37 - 55

Laventhal, G.S (1980) What Should Be Done With Equity Theory? In K.J. Gergen, M.S Greenberg and R.H Willis (Eds), Social Exchange: In Theory And Research, 27 - 55; New York: Plenum Press

Leach - Lopez, M.A, StammerJohan, W.W. \& McNair, F.M.(2007) Differences in the role of job relevant information in the budget - participation - performance relationship among U.S. and Mexican managers: A question of culture or communication, Journal of management Accounting Research, 19:105-136

Levanthal, G.S (1980) What should be done with equity theory In K.J. Gergen, M.S Green Berg \& R.H. Willia (Eds), Social Exchange: Advances In Theory And Research, 27 - 55, New York: Plenum Press

Libby, T (2001) Referent cognitions and budgeting fairness: a research note, Journal of Management Accounting Research, 13 (1): 91 - 105

Libby, T(1999) The influence of voice and explanation on performance on participative budgeting setting, Accounting, organization and society

Lincoln, J.R. \& Kalleberg, A.L. (1985) Work organisation and work place commitment: a study of plants and employees in The U.S And Japan American Sociological Review: 738 760

Lind, E.A \& Tyler, T.R. (1988) The social psychology of procedural justice, New York: Plenum Press.

Locke, E.A, Schweiger, D. M. \& Latham, G.P. (1986) Participation in decision making: when should it be used? Organizational Dynamics 16(winter): $65-79$.

Magner, N., Welker,R.B. \& Campbell, T.L. (1996) Testing a model of cognitive budgetary participation processes in a latent variable structural equation framework, Industrial Relations, $97-110$

Maiga, A.S \& Jacobs, F.A. (2007) Budget participation's influence on budget stack: The role of fairness perceptions, trust and goal commitment, JAMAR 5(1): $39-58$

Manger, N \& Johnson, G.G. (1995) Municipal officials' relations to justice in budgetary resource allocation Public Administrative Quarterly 18(4):439 - 456.

Maruyana, G.M. (1998) Basics of Structural Equation Modeling, London: Sage Publications

Merchant, K.A (1981) The design of the cooperate budgeting system: influences on managerial behaviour and performance, The Accounting Review, 56(October): 813 - 829

Meyer, J.P \& Allen, N.J. (1984) Testing the side - belt - theory of organizational commitment: some methodological considerations Journal Of Applied Psychology, 69:372 - 378 
Meyer, J.P and Allen, N.J. (1991) A Three - Component Conceptualization Of Organizational Commitment, Human Resource Management Review, 1(1) 61 - 89

Mia, L. (1989) The Impact of Participation in Budget Setting and Job Difficulty on Managerial Performance and Work Performance: A Research Note Accounting Organizational and Society 14(4): 347 - 357

Milani, K.W. (1975) The relationship of participation in budget setting industrial supervisors' performance and attitudes: A field study The Accounting Review, April: 274 - 285

Mowday, R.T (1998) Reflections on the study and relevance of organizational Commitment Human Resource Management Review, 8(4) :387 - 401

Murray, D(1990) The performance effects of participative budgeting: An integration of intervening and moderating Variables Behavioural research in Accounting, 2(2): 104 123

Noun, H \& Parker, R.J. (1996) The effect of organizational commitment on the relation between budgetary participation and budgetary slack, Behavioural Research In Accounting, 8:7490

Nouri, H \& Parker, R.J. (1996) The relationship between budget participation and job performance: The role of budget adequacy and organisational commitment Accounting, Organization And Society, 20:283 - 404

Nowday, R.T. Steers \& Porter, L.W. (1979) The measurement of organisational commitment Journal Of Vocational Behaviour", 14:224-247

O Connor, N. (1995) The influence of organisational culture on the usefulness of budget participation by Singaporean - Chinese manager, Accounting, organizations and Society, $20: 383-404$.

Otley, D. T (1978) Budget use and managerial performance, Journal Of Accounting Research 16(1): 122-149

Oyen, C. (1991) Job difficulty as a moderate of the effect of budgetary participation on employee performance, The Journal Of Social Psychology 132(5): 695 - 696.

School, R.W (1981) Differentiating commitment from expectancy as a motivational force Academy Of Management Review, 6:589 - 599

Shapiro, D.L \& Brett, J.M. (1993), Comparing three process underlying judgments of procedural justice: A filed study of mediation and arbitration, Journal Personality and Social Psychology, 65:1167-1177.

Shields, J.F \& Shields, M.D. (1998) Antecedents of participative budgeting Accounting, Organization and Society, 23(1): $49-7$

Shields, J.F \& Shields, M.D (1998) Antecedents of Participative Budgeting, Organizations and Society 23(1): 49 - 76

Shields, M.D, Deng, F.J. \& Kato,Y (2000) The Design and Effects of Control Systems: Test of Direct - and Indirect Effects Models, Accounting, Organization and Society,. 25(2) 185 $-202$

Sholihin, M.R Pike \& Managena, M. (2007) The moderating effects of procedural fairness and distributive fairness on the relationship between performance evaluation styles a and job satisfaction, Bradford: Working Paper No. 07/28, Working Paper Series.

Southwood, K.E.(1978) Substantive theory and statistical interaction: five models, American Journal of Sociology, 83(March): 1154 - 1203 
Subramaniam N and N.M Ashkanasy(2001) The effect of organizational culture perceptions on the relationship between budgetary participation and managerial job related outcomes Australian Journal Of Management, 26(1): 35 - 54

Suleiman, A.M and Isles, P.A. (2000a) Is continuance commitment beneficial to organisation Commitment - performance relationship; a new look, Journal Of Managerial Psychology, 15(5): $407-426$

Suleiman, A.M. and Isles, P.A.(2000b) The Multi - Dimensional Nature Of Organizational Commitment In A Non- Western Context, Journal of Management Development, 19(1): $71-82$

Thibaut, J.N., Friend, L. \& Walker, L. (1974) Compliance with rule: some social Determinants Journal of Personally and Social Psychology, 30:782-801

Thibaut, J.N \& Walker, L.(1975) Procedural justice: A psychology analysis, New York: Wiley

Tiller, M.G. (1983) the dissonance model of participative budgeting: An empirical exploration Journal of Accounting Research, 21(2): 581 - 59

Tsui, J. S. L (2001) The impact of culture on the relationship between participation, management accounting systems and managerial performance: an analysis of chinese and western managers, The international Journal of Accounting, 36: 125 - 146

Weiner, O.F. (1982) Commitment in organisation: A normative view, Academy Of Management Review 23(3): $513-531$

Wentze, K. (2002) The influence of fairness perception and goal commitment on managers performance in a budget setting, Behavioural Research In Accounting, 14:247 - 271

\begin{tabular}{|l|l|c|c|c|c|c|}
\hline S/N & DESCRIPTION & SA & A & UD & D & SD \\
\hline & SECTION A :BUDGET PARTICIPATION & & & & & \\
\hline 1 & I am involved in setting on my final budget. & & & & & \\
\hline 2 & My superior clearly explains budget revision to me & & & & & \\
\hline 3 & I have frequent budget related discussion with my superior. & & & & & \\
\hline
\end{tabular}




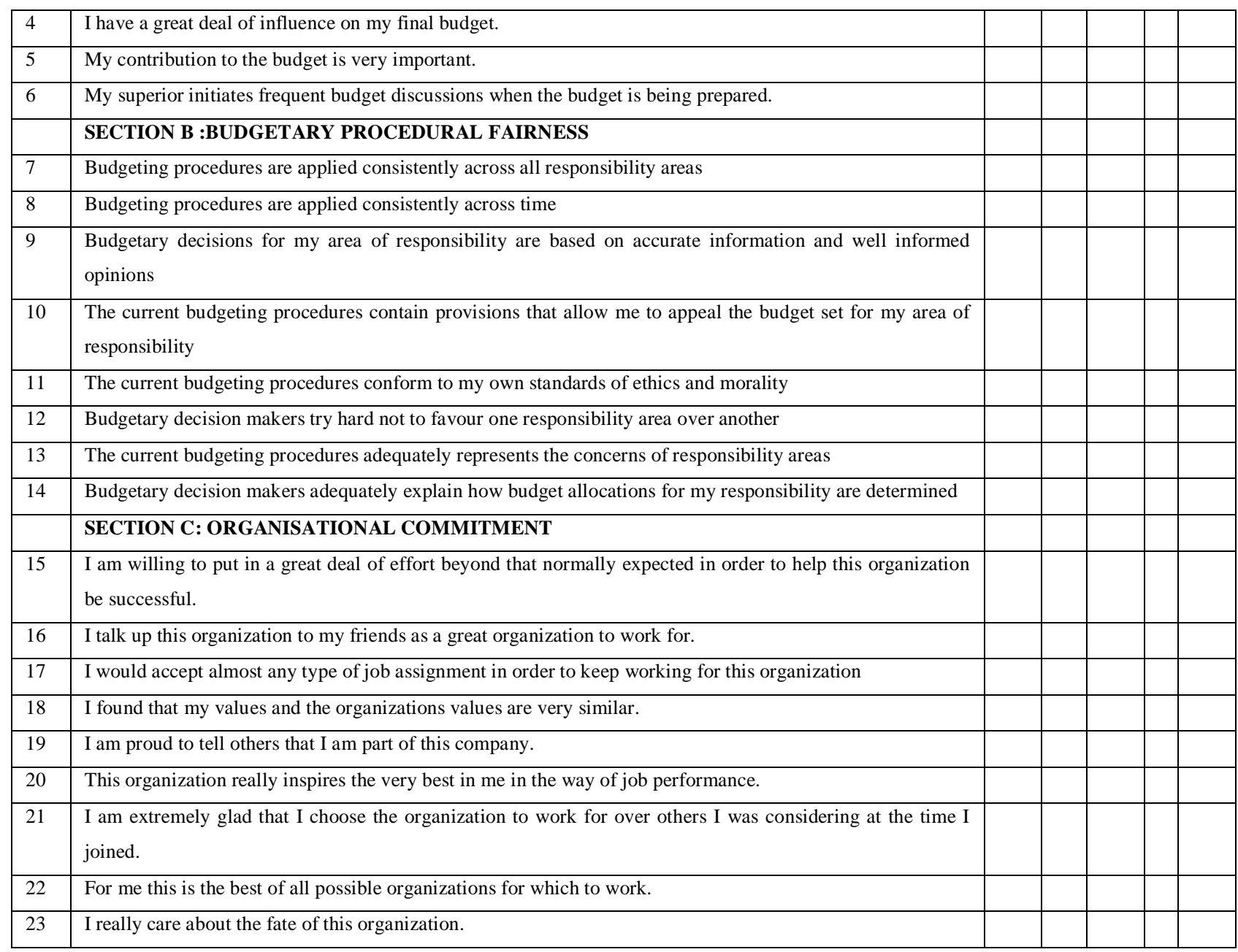

\section{Section D: Performance}

Rate your performance as a man

\begin{tabular}{|l|l|l|l|l|l|l|}
\hline S/N & TASK & VERY HIGH & HIGH & MODERATE & LOW & VERY SLOW \\
\hline 24 & Planning & & & & & \\
\hline 25 & Investigation & & & & & \\
\hline 26 & Coordinate & & & & & \\
\hline 27 & Evaluating & & & & & \\
\hline 28 & Supervising & & & & & \\
\hline 29 & Staffing & & & & & \\
\hline 30 & Negotiating & & & & & \\
\hline 31 & Representing & & & & & \\
\hline 32 & Overall performance & & & & & \\
\hline
\end{tabular}

